\title{
The Status Quo of Crisis Management Implementation in Jordanian Public Secondary Schools in Amman, According to Impact Effort Matrix, from the Point of View of its School Leaders
}

\author{
Manal Qtishat Prof. Anmar Kaylani
}

\begin{abstract}
The present study aimed at identifying the status quo of crisis management implementation in Jordanian public secondary schools in Amman, according to Impact Effort Matrix, from the point of view of its school leaders. The study sample consisted of (250) principals and teachers in Jordanian public secondary schools in Amman. The questionnaire consisted of (3) dimensions and (78) statements. It was found that the status quo of crisis management implementation in Jordanian public secondary schools in Amman, according to Impact Effort Matrix, from the point of view of its school leaders was moderate. It was also found that there were significant differences in the means for the second and third dimensions that can be attributed to sex, they came in favour of males, and it was found that there were significant differences in the means for the first dimension that can be attributed to educational qualifications, they came in favour of higher education.whereas, no significant differences in the status quo of crisis management implementation in Jordanian public secondary schools in Amman, according to Impact Effort Matrix, from the point of view of its school leaders that can be attributed to experience and position were found. Based on the results, several recommendations were presented such as reviewing and revisiting the roles of principals, conducting studies related to crisis management and establishing a specialized department for crisis management in secondary schools.
\end{abstract}

Keywords: Crisis Management, Impact Effort Matrix, Secondary Schools, School Leaders.

DOI: $10.7176 / \mathrm{JEP} / 11-20-04$

Publication date:July $31^{\text {st }} 2020$

\section{Introduction}

Crises, with its multiple and different forms, is considered a condition inherent to humans in every aspect and time, they occur in both developed and developing countries, with a difference in nature and depth of impact. The world today witnesses many crises, whether they occur locally or within the Arab World or in an international level, yet, the degree of their occurrence varies at the individual and collective levels, according to the way they are organized, and conscious societies are the ones that plan the present and future of their children.

"The educational system is an integral part of the society; therefore, it is imperative to face challenge, difficulties and crises by setting plans for them. Educational institutions are one of the largest institutions, in terms of size and services, they are also part of the country's entity that are affected by crises. These crises affect a large group of people and the society. The school maybe faced with critical and crucial points in which the causes are mixed with results, its principals lose their ability to deal with them and take appropriate decisions about them in light of uncertainty, time constraints and lack of information, which hinders the school from achieving its goals and causing materialistic and human losses". (Al-Yahyawi, 2006, p.310).

The importance of crisis management comes from the seriousness of crises on the educational institutions first, and on society second, due to the close association between them, which makes identifying the educational crisis management requirements in secondary schools in the current circumstances very important, taking into consideration that the success of schools in managing crises depends on providing requirements (material, administrative, and human).

Therefore, the crises is faced by all institutions, whether they were educational or non - educational, small or large, the difference between these institutions is in how to deal with those crises, but the scientific methods in crisis management consists of: planning, organization, direction, following-up, leadership, communication system, information system, decision-making, and evaluation. (Al Yahya, 2006, p.309).

There should be a link between crisis management efforts and an economical managerial standard that refers to the access to the ideal point of crisis management procedures, these procedures were reviewed and Impact Effort Matrix was the most suitable, as it is a matrix that consists of instruments that assists in making decisions through weighing a number of options presented, and depending on two main factors: the effort required to achieve the task and the impact from achieving the task.

There are general steps to use this tool; through discussing the ideas presented and possible solutions from the crisis team, and then assessing the expected impact of implementing each idea, and evaluating the effort required to achieve the task and the impact from achieving the task. There are some factors that should be taken into account such as: Ease of implementation, implementation costs, required resources, budget and its readiness 
at the appointed time, in addition to the availability of the techniques required for implementation, the skills and processes necessary to ensure successful implementation, and then representing the points graphically through the values that were established for impact and effort, choosing the solutions that will be implemented depending on their impact and effort, the evaluation is presented in two axes; one horizontal representing the impact, and the other vertical representing the required effort, these are distributed in four squares: big impact and little effort, big impact, little impact and big effort, little impact and little effort, and sometimes it is replaced by awarding points for each of the available solutions by evaluating them on a scale of three options for both effort and impact, these options are: high, medium, and low .(Qasim, 2017, p.174).

Based on the above, and despite the existence of studies about crises facing public and private schools specially in Amman, it is noted that the existence of studies that combine crises and their management in an organized scientific way are rare, hence the importance of studying the status quo of the implementation of crisis management facing secondary schools, and how to manage them using the Impact Effort Matrix, has emerged. This study comes to identify the crises facing schools, and to review crisis management, and its relationship to management as viewed by educational leaders and teachers in secondary schools.

\section{Statement of the problem and study's questions:}

Today, schools are facing many crises that may affect education, the occurrence of crises is an inevitable status quo that educational institutions face and are affect by, also the occurrence of crises affect the safety of institutions' staff and property. This calls for intervention to face crises in a timely manner before aggravation, and to maintain the development and growth of the institution in light of the accelerated global challenges; this resulted in a variation in the roles of public school principals in term of dealing with these crises.

Furthermore, the lack of a single agreed on template on how to deal with these crises, forced the principals to make their own judgments.

In light of the current situation, the conditions that schools are facing, and the experiences that school principals go through, it is important to identify and clarify the methods and procedures for managing and dealing with school crises through the advance planning for these crises, abandoning random and traditional methods and replacing them with scientific methods.

Based on the above-mentioned information, the study's problem is represented by the following questions: Q.1 What is the status quo of crisis management implementation in Jordanian public secondary schools in Amman, according to Impact Effort Matrix, from the point of view of its school leaders?

Q.2Are there any significant differences at $(\mathrm{a}=0.05)$ in the status quo of crisis management implementation in Jordanian public secondary schools in Amman, according to Impact Effort Matrix, from the point of view of its school leaders, which can be attributed to sex, experience, position or educational qualification?

\section{Study's objectives}

The present study aimed at identifying the status quo of crisis management implementation in Jordanian public secondary schools in Amman, according to Impact Effort Matrix, from the point of view of its school leaders.

\section{Study's significance}

- Hopefully, the present study will enable the following authorities to benefit from its results:

- Decision-makers, secondary schools' principals, and teachers to circulate and implement the results

- Researchers to make use of theoretical literature and the results of this study.

\section{The study's definitions:}

\subsection{Crisis Management:}

It is defined as an administrative style that depends on prior planning processes, purposeful organization and effective communication to deal with crises facing schools in order to reduce the damage caused by them, and their negative effects on students, administrators, teachers, and parents, this can be done through enabling and empowering schools' administrations to deal with them. (Kahil, 2015, p.210).

For this study, the procedural definition is: the activities and procedures that the school principal adopts, in collaboration with his staff, to face the school crises in a scientific way based on good prediction, identifying the roles and tasks, and the rapid movement to reduce its negative effects, in order to return the school to its stable position.

\subsection{Impact Effort Matrix:}

It refers to a tool for decision-making by comparing a number of options presented depending on the effort required to make the decision and the impact of implementing the decision (Qasim, 2017, p.173).

For this study, the procedural definition is: General steps that are made to use this tool, these steps are: ideas discussion, evaluating the expected impact, evaluating the effort, presenting the points graphically, and choosing 
the solutions that will be implemented

5.3 Secondary Schools:

The stage that follows the primary (preparatory) stage, it starts from the tenth grade to the end of the twelfth grade, and the average ages for students is between 15-17 years. (Hamdounah, 2006, p. 8).

For this study, the procedural definition is: The school that has secondary grades, in specific first and second secondary grades.

\subsection{School Leaders:}

The ability of the school principal to influence the behavior of school personnel, primarily teachers, to work with desire, in order to achieve school goals (Al-Saud, 2014, p. 293).

For this study, the procedural definition is: Persons officially assigned to achieve secondary school educational goals, by directing the school's staff activity, encouraging them to interact very efficiently, and achieving a high degree of satisfaction and confidence among the school's staff..

\section{Study's limits:}

- Thematic limits: This study shed light on the status quo of thecrisis management implementation in Jordanian public secondary schools in Amman, according to Impact Effort Matrix, from the point of view of its school leaders.

- Human limits: This study sampled several principals and teachers in Jordanian public secondary schools in Amman

- Spatial limits: This study was restricted to public secondary schools in Amman

- Temporal limits: This study was conducted in the academic year 2019/2020.

\section{Previous Studies:}

Al-Salhi and Ibtisam Bint Ibraheem (2019), aimed at identifying the status quo of the implementation of decisions making in order to manage school crises by secondary school female leaders in the Qassim region in Saudi Arabia from the viewpoint of female school leaders and female school leadership supervisors, it also aimed at identifying the difficulties they face when implementing. It was found that the status quo of the implementation of decisions making in order to manage school crises by secondary school female leaders in the Qassim region in Saudi Arabia from the viewpoint of female school leaders and female school leadership supervisors was high, it was also found that there were significant differences attributed to the difference in the current work, they came in favor of secondary school female leaders, whereas no significant differences that can be attributed to the different years of experience and educational qualification were found

Al-Thuwaini (2018), aimed at identifying what a secondary school crisis is, it also aimed at identifying what crises management in secondary schools is and the role of personnel in facing them, moreover, it aimed at identifying the status quo of crisis management skills for secondary school teachers in Ha'el, Saudi Arabia. It was found that the status quo of secondary schools handling the crises were low, due to lack of awareness of the importance of crisis management and the feasibility of implementing it. It was also found that the modern approaches in crises management were not implemented in secondary schools in the city of Ha'el.

Al-Juhani (2018), aimed at identifying the status quo of school leaders' practicing decision-making in managing school crises, it also aimed at identifying methods for developing the competences of school leaders in Yanbu, Saudi Arabia to take appropriate decisions in managing school crises. It was found that the status quo of school leaders practicing decision-making in managing school crises was high, it was found that there were significant differences in the experience in school administration variable, they came in favor of higher administrative experience.

Abdullah (2018), aimed at identifying the status quo of the effectiveness of secondary school principals in managing school crises in Muscat, Oman. It was found that there were weaknesses in the ability to predict as well as a lack of attention to school crises by secondary schools' principals. It was also found that there were significant differences in the educational qualification variable, which came in favor of postgraduate studies, also, there were significant differences in the educational stage variable, that came in favor of school principals in the secondary stage.

Tokel (2018), aimed at identifying the effects of crisis management skills on secondary school principals in Turkish Republic of Northern Cyprus, it also aimed at providing suggestions about crisis management in schools in the light of the information obtained. It was found that there were types of crises facing secondary school principals, it also determined the obstacles preventing the crisis from resolving, and the measures taken to prevent the crisis from occurring again.

Rengifo, Ruz \& Mascareño (2018), aimed at analyzing crisis management in schools in the Midwest of Chile, and explore emerging aspects of their response to the school crisis using the Chaos-Based Dynamic Life 
Cycle of a Crisis Model. It was found that the Dynamic Life Cycle of a Crisis Model is useful in understanding and addressing the school crisis and its subsequent effects, but also has the capabilities of flexibility and cooperation,

Liou (2015), aimed at exploring the emerging aspects from its response to a school crisis in the Midwest Midwestern Pk-12. It also aimed at analyzing school crisis management using Dynamic Life Cycle of a Crisis Model. It was found that the Dynamic Life Cycle of a Crisis Model is useful in recognizing and addressing the school crisis and its subsequent effects, but has potential limitations in the chain design, flexibility and cooperation, it was also found that there is no one way that fits all for crisis management.

\section{Study's Approach:}

A descriptive survey research approach was adopted. It was adopted to identify the status quo of thecrisis management implementation in Jordanian public secondary schools in Amman, according to Impact Effort Matrix, from the point of view of its school leaders. By referring to the previous studies related to the subject of the study, then collecting data using the study tool and statistically analyzing it to answer the study questions.

\section{Study's Population and Society:}

The population is represented by (307) principals and (9934) teachers. The sample included (250) principals and teachers, from public secondary schools in Amman. Data about that is displayed below in table (1)

Table (1): Distribution of the study's respondents in accordance with (sex, experience, and educational qualifications)

\begin{tabular}{|c|l|r|r|}
\hline Variable & Category & Frequency & Percentage \\
\hline \multirow{5}{*}{ Sex } & Male & 108 & $43 \%$ \\
\cline { 2 - 4 } & Female & 142 & $57 \%$ \\
\cline { 2 - 4 } & Total & 250 & $100 \%$ \\
\hline \multirow{5}{*}{ Experience } & Less than 5 years & 53 & $21 \%$ \\
\cline { 2 - 4 } & Over 5 years to 10 years & 85 & $34 \%$ \\
\cline { 2 - 4 } & More than 10 years & 112 & $45 \%$ \\
\cline { 2 - 4 } & Total & 250 & $100 \%$ \\
\hline \multirow{3}{*}{ Educational } & Bachelor's & 171 & $68 \%$ \\
\cline { 2 - 4 } & Postgraduate & 79 & $32 \%$ \\
\cline { 2 - 4 } & Total & 250 & $100 \%$ \\
\hline \multirow{3}{*}{ Position } & Principal & 48 & $19 \%$ \\
\cline { 2 - 4 } & Teacher & 202 & $81 \%$ \\
\cline { 2 - 4 } & Total & 250 & $100 \%$ \\
\hline
\end{tabular}

\section{Study's Instrument:}

A questionnaire was developed after reviewing the relevant studies. This questionnaire consisted of (3) dimensions and (78) statementsthat aimed at identifying the status quo of thecrisis management implementation in Jordanian public secondary schools in Amman, according to Impact Effort Matrix, from the point of view of its school leaders. These dimensions were: (Early Warning Signals, Procedures Used to Avoid the Occurrence of the Crisis, Degree of School Readiness to Manage the Crises).

\section{Validity of the Instrument}

To measure the validity of the questionnaire, Content Validity method was used. The initial questionnaire was passed to (10) experts from different Jordan universities faculty, who have the required expertise. They were asked to assess the questionnaire and provide their feedback regarding language, relevance, and validity to measure what it was designed for. They were also asked to give suggestions regarding additions, deletions, and adjustments.

\section{Reliability of the questionnaire:}

To measure the reliability of the questionnaire, Cronbach alpha coefficient was used. the values ranged between (0.88 and 0.91$)$. This indicates that the questionnaire has a high degree of reliability. Table (2) shows Cronbach alpha coefficient values. 
Table (2): Cronbach alpha coefficient values for each dimension

\begin{tabular}{|c|c|c|}
\hline Dimension & $\begin{array}{l}\text { Cronbach alpha } \\
\text { coefficient }\end{array}$ & $\begin{array}{l}\text { Number of } \\
\text { statements }\end{array}$ \\
\hline 1. Early Warning Signals & 0.88 & 23 \\
\hline $\begin{array}{l}\text { 2. Procedures Used to Avoid the Occurrence of the } \\
\text { Crisis }\end{array}$ & 0.84 & 11 \\
\hline 3. Degree of School Readiness to Manage the Crises & 0.91 & 44 \\
\hline
\end{tabular}

\section{Criteria for classifying means:}

A response ladder was adopted using the following formula: 1.00 - 1.66: low1.67-2.33: moderate 2.34 - 3: high

\section{Study's variables:}

The present study included the following variables:

- Independent variable: The status quo of crisis management implementation in Jordanian public secondary schools in Amman, according to Impact Effort Matrix, from the point of view of its school leaders. The study sample consisted of (250) principals and teachers in Jordanian public secondary schools in Amman.

- Moderate variables: Three variables related to school leaders, which are:

- Sex: It had two categories: Males and Females

- Educational Qualification: It had two levels: Bachelor's, Postgraduate.

- Experience: It had three categories: Less than 5 years, over 5 years to 10 years, and more than 10 years.

- Position: It had to categories: Principals and Teachers

- Dependent variables: School leaders.

\section{Statistical analysis:}

Different statistical analysis methods were used to analyze data and to answer the study's two questions such as means, standard deviation, and Cronbach alpha coefficient.

\section{Results and discussion:}

16.1. Results and discussion related to the study's first question: Q.1 What is the status quo ofcrisis management implementation in Jordanian public secondary schools in Amman, according to Impact Effort Matrix, from the point of view of its school leaders?

To answer this question, means and standard deviations for the status quo of crisis management implementation in Jordanian public secondary schools in Amman, according to Impact Effort Matrix, from the point of view of its school leaderswere calculated. These values are captured in table (3) below

Table (3): The status quo of crisis management implementation in Jordanian public secondary schools in Amman, according to Impact Effort Matrix, from the point of view of its school leaders?

\begin{tabular}{|l|l|l|l|l|l|}
\hline $\begin{array}{l}\text { Dimension } \\
\text { Number }\end{array}$ & Rank & Dimension & Mean & Std. & Level \\
\hline 2 & 1 & Procedures Used to Avoid the Occurrence of the Crisis & 2.19 & 0.472 & Moderate \\
\hline 3 & 2 & Degree of School Readiness to Manage the Crises & 2.12 & 0.391 & Moderate \\
\hline 1 & 3 & Early Warning Signals & 1.94 & 0.396 & Moderate \\
\hline \multicolumn{2}{|l}{ Total } & 2.08 & 0.344 & Moderate \\
\hline
\end{tabular}

Based on the results shown in table (3), The status quo of the crisis management implementation in Jordanian public secondary schools in Amman, according to Impact Effort Matrix, from the point of view of its school leaders is moderate. The overall mean is (2.08) and the total standard deviation is (0.344).Procedures Used to Avoid the Occurrence of the Crisis dimension is ranked first with a mean of (2.19) which is moderate, and with a standard deviation of (0.472),whereas Degree of School Readiness to Manage the Crises dimension ranked second with a mean of (2.12) which is moderate, and with a standard deviation of (0.391), and finally, Early Warning Signals dimension ranked third with a mean of (1.94) which is moderate, and with a standard deviation of (0.396). This results indicates that the roles of principals and how to deal with crises should be reviewed and revisited, it also indicates that there is a crisis management system in schools, but it faces some problems and challenges that limit its improvement to reach the required level, there are also some shortcomings in the implementation of crisis management in secondary schools, due to administrative bureaucracy, mediation in appointing staff without taking into consideration qualifications and experience, the lack of a clear mission and vision regarding managing crises, and the absence of training and continuous learning for leaders and staff on crisis management. However, the results indicate that there is a crisis management culture within school leaders and is implemented at an acceptable level in public secondary schools. 
16.2. Results and discussion related to the study's third question: Q.3 Are there any significant differences at $(a=0.05)$ in the status quo of crisis management implementation in Jordanian public secondary schools in Amman, according to Impact Effort Matrix, from the point of view of its school leaders, which can be attributed to sex, experience, position or educational qualification?

To answer this question, means and standard deviations for procedures to identify the status quo of crisis management implementation in Jordanian public secondary schools in Amman, according to Impact Effort Matrix, from the point of view of its school leaders, which can be attributed to sex, experience, position or educational qualification were calculated. These values are captured in table (4)

Table (4): Means and standard deviations for each dimension of the questionnaire

\begin{tabular}{|c|c|c|c|c|c|}
\hline Variable & Dimension & Category & Frequency & Means & Std. \\
\hline \multirow{8}{*}{ Sex } & \multirow{2}{*}{ Early Warning Signals } & Male & 108 & 1.901 & 0.406 \\
\hline & & Female & 142 & 1.976 & 0.388 \\
\hline & \multirow{2}{*}{$\begin{array}{l}\text { Procedures Used to Avoid } \\
\text { the Occurrence of the Crisis }\end{array}$} & Male & 108 & 2.397 & 0.372 \\
\hline & & Female & 142 & 2.038 & 0.482 \\
\hline & \multirow{2}{*}{$\begin{array}{l}\text { Degree of School Readiness } \\
\text { to Manage the Crises }\end{array}$} & Male & 108 & 2.226 & 2.046 \\
\hline & & Female & 142 & 2.046 & 0.415 \\
\hline & \multirow{2}{*}{ Total } & Male & 108 & 2.155 & 0.295 \\
\hline & & Female & 142 & 2.024 & 0.369 \\
\hline \multirow{12}{*}{ Experience } & \multirow{3}{*}{ Early Warning Signals } & 1-5 Years & 53 & 1.896 & 0.434 \\
\hline & & Over $5-10$ years & 85 & 1.925 & 0.367 \\
\hline & & More than 10 years & 112 & 1.981 & 0.400 \\
\hline & \multirow{3}{*}{$\begin{array}{l}\text { Procedures Used to Avoid } \\
\text { the Occurrence of the Crisis }\end{array}$} & $1-5$ Years & 53 & 2.304 & 0.504 \\
\hline & & Over 5 - 10 years & 85 & 2.201 & 0.482 \\
\hline & & More than 10 years & 112 & 2.136 & 0.442 \\
\hline & \multirow{3}{*}{$\begin{array}{l}\text { Degree of School Readiness } \\
\text { to Manage the Crises }\end{array}$} & $1-5$ Years & 53 & 2.172 & 0.388 \\
\hline & & Over 5 - 10 years & 85 & 2.136 & 0.388 \\
\hline & & More than 10 years & 112 & 2.092 & 0.397 \\
\hline & \multirow{3}{*}{ Total } & $1-5$ Years & 53 & 2.109 & 0.358 \\
\hline & & Over 5 - 10 years & 85 & 2.083 & 0.326 \\
\hline & & More than 10 years & 112 & 2.065 & 0.353 \\
\hline \multirow{8}{*}{$\begin{array}{l}\text { Educational } \\
\text { Qualification }\end{array}$} & \multirow{2}{*}{ Early Warning Signals } & Bachelor's & 171 & 1.864 & 0.381 \\
\hline & & Postgraduate & 79 & 2.116 & 0.377 \\
\hline & \multirow{2}{*}{$\begin{array}{l}\text { Procedures Used to Avoid } \\
\text { the Occurrence of the Crisis }\end{array}$} & Bachelor's & 171 & 2.207 & 0.474 \\
\hline & & Postgraduate & 79 & 2.163 & 0.470 \\
\hline & \multirow{2}{*}{$\begin{array}{c}\text { Degree of School Readiness } \\
\text { to Manage the Crises }\end{array}$} & Bachelor's & 171 & 2.120 & 0.381 \\
\hline & & Postgraduate & 79 & 2.132 & 0.416 \\
\hline & \multirow{2}{*}{ Total } & Bachelor's & 171 & 2.057 & 0.329 \\
\hline & & Postgraduate & 79 & 2.132 & 0.371 \\
\hline \multirow{8}{*}{ Position } & \multirow{2}{*}{ Early Warning Signals } & Principal & 48 & 2.117 & 0.385 \\
\hline & & Teacher & 202 & 1.903 & 0.389 \\
\hline & \multirow{2}{*}{$\begin{array}{l}\text { Procedures Used to Avoid } \\
\text { the Occurrence of the Crisis }\end{array}$} & Principal & 48 & 2.125 & 0.488 \\
\hline & & Teacher & 202 & 2.210 & 0.468 \\
\hline & \multirow{2}{*}{$\begin{array}{l}\text { Degree of School Readiness } \\
\text { to Manage the Crises }\end{array}$} & Principal & 48 & 2.111 & 0.408 \\
\hline & & Teacher & 202 & 2.127 & 0.389 \\
\hline & \multirow{2}{*}{ Total } & Principal & 48 & 2.120 & 0.427 \\
\hline & & Teacher & 202 & 2.080 & 0.415 \\
\hline
\end{tabular}

Based on the results shown in table (4), there are apparent differences in the means for the status quo of crisis management implementation in Jordanian public secondary schools in Amman, according to Impact Effort Matrix, from the point of view of its school leaders, which can be attributed to sex, experience, position or educational qualification. To investigate the significance of these differences, Multivariate Analysis of Variance (MANOVA) was conducted. The results are displayed through table (5) below: 
Table (5): The results of the Multivariate Analysis of Variance (MANOVA) for each dimension

\begin{tabular}{|c|c|c|c|c|c|c|}
\hline Variable & Dimension & $\begin{array}{c}\text { Type III Sum of } \\
\text { Squares }\end{array}$ & Df. & $\begin{array}{c}\text { Mean } \\
\text { Square }\end{array}$ & F. & Sig. \\
\hline \multirow{3}{*}{ Sex } & Early Warning Signals & 0.316 & 1 & 0.316 & 2.189 & 0.14 \\
\hline & $\begin{array}{l}\text { Procedures Used to Avoid the } \\
\text { Occurrence of the Crisis }\end{array}$ & 7.078 & 1 & 7.078 & 36.512 & 0 \\
\hline & $\begin{array}{l}\text { Degree of School Readiness to } \\
\text { Manage the Crises }\end{array}$ & 1.769 & 1 & 1.769 & 11.939 & 0.001 \\
\hline \multirow{3}{*}{ Experience } & Early Warning Signals & 0.031 & 2 & 0.015 & 0.107 & 0.899 \\
\hline & $\begin{array}{l}\text { Procedures Used to Avoid the } \\
\text { Occurrence of the Crisis }\end{array}$ & 0.152 & 2 & 0.076 & 0.391 & 0.677 \\
\hline & $\begin{array}{l}\text { Degree of School Readiness to } \\
\text { Manage the Crises }\end{array}$ & 0.084 & 2 & 0.042 & 0.282 & 0.755 \\
\hline \multirow{3}{*}{$\begin{array}{l}\text { Educational } \\
\text { Qualification }\end{array}$} & Early Warning Signals & 2.002 & 1 & 2.002 & 13.863 & 0 \\
\hline & $\begin{array}{l}\text { Procedures Used to Avoid the } \\
\text { Occurrence of the Crisis }\end{array}$ & 0.064 & 1 & 0.064 & 0.329 & 0.567 \\
\hline & $\begin{array}{l}\text { Degree of School Readiness to } \\
\text { Manage the Crises }\end{array}$ & 0.005 & 1 & 0.005 & 0.037 & 0.848 \\
\hline \multirow{3}{*}{ Position } & Early Warning Signals & 0.154 & 1 & 0.154 & 1.067 & 0.303 \\
\hline & $\begin{array}{l}\text { Procedures Used to Avoid the } \\
\text { Occurrence of the Crisis }\end{array}$ & 0.009 & 1 & 0.009 & 0.046 & 0.83 \\
\hline & $\begin{array}{l}\text { Degree of School Readiness to } \\
\text { Manage the Crises }\end{array}$ & 0.013 & 1 & 0.013 & 0.089 & 0.766 \\
\hline \multirow{3}{*}{ Error } & Early Warning Signals & 35.24 & 244 & 0.144 & & \\
\hline & $\begin{array}{l}\text { Procedures Used to Avoid the } \\
\text { Occurrence of the Crisis }\end{array}$ & 47.298 & 244 & 0.194 & & \\
\hline & $\begin{array}{l}\text { Degree of School Readiness to } \\
\text { Manage the Crises }\end{array}$ & 36.147 & 244 & 0.148 & & \\
\hline \multirow{3}{*}{ Total } & Early Warning Signals & 39.202 & 249 & & & \\
\hline & $\begin{array}{l}\text { Procedures Used to Avoid the } \\
\text { Occurrence of the Crisis }\end{array}$ & 55.487 & 249 & & & \\
\hline & $\begin{array}{l}\text { Degree of School Readiness to } \\
\text { Manage the Crises }\end{array}$ & 38.231 & 249 & & & \\
\hline
\end{tabular}

Based on the results in table (5), the value of " $F$ " for Sex variable dimensions was as follows: (2.189) for Early Warning Signalsdimension, (36.512) for Procedures Used to Avoid the Occurrence of the Crisis dimension, (11.939) for Degree of School Readiness to Manage the Crises dimension, There are significant values at the significance level of (0.05) for Procedures Used to Avoid the Occurrence of the Crisis and Degree of School Readiness to Manage the Crises dimensions, which indicates that there are significant differences. It came in favour of males, This may be attributed to the fact that males are more strong, tough and can control their emotions and feelings more during dealing with crises, facing them and responding to them, and are more aware of the problems facing them than females who may be overpowered by their emotions and feelings, which prevents their identification and awareness of crises in a scientific and accurate manner.

Based on the results in table (5), the value of " $F$ " for Experience variable dimensions was as follows: (0.107) for Early Warning Signals dimension, (0.391) for Procedures Used to Avoid the Occurrence of the Crisis dimension, (0.282) for Degree of School Readiness to Manage the Crises dimension, There are insignificant values at the significance level of $(0.05)$ for all dimensions, which indicates that there are no significant differences.

Based on the results in table (5), the value of "F" for Educational Qualification variable dimensions was as follows: (13.863) for Early Warning Signals dimension, (0.329) for Procedures Used to Avoid the Occurrence of the Crisis dimension, (0.037) for Degree of School Readiness to Manage the Crises dimension, There are significant values at the significance level of (0.05) for Degree of School Readiness to Manage the Crises dimension, which indicates that there are significant differences. It came in favour of postgraduate, this may be attributed to the fact that school principals with higher educational qualifications acquired the necessary information and knowledge during their studies, which made them more aware of the status quo of the school crises that impede schools, and they were more able to develop plans and readiness to manage crises.

Based on the results in table (5), the value of "F" for Position variable dimensions was as follows: (1.067) 
for Early Warning Signals dimension, (0.046) for Procedures Used to Avoid the Occurrence of the Crisis dimension, (0.089) for Degree of School Readiness to Manage the Crises dimension, There are insignificant values at the significance level of (0.05) for all dimensions, which indicates that there are no significant differences.

\section{Conclusion and Recommendations:}

It was found that the status quo of the crisis management implementation in Jordanian public secondary schools in Amman, according to Impact Effort Matrix, from the point of view of its school leaders is moderate. The overall mean is (1.94). This signifies that there is a crisis management culture within school leaders and is implemented at an acceptable level in public secondary schools, however, the crisis management system in schools faces some problems and challenges that limit its improvement to reach the required level.

It was also found that there are significant differences in the means for the second and third dimensions that can be attributed to sex, they come in favour of males, and there are significant differences in the means for the first dimension that can be attributed to educational qualifications, they come in favour of higher education. However, no significant differences in the status quo of crisis management implementation in Jordanian public secondary schools in Amman, according to Impact Effort Matrix, from the point of view of its school leaders that can be attributed to experience and position are found.

In the light of the study's results, the followings are recommended:

- Revisit the roles of school principals.

- Draw educational leaders' attention to the importance of implementing crisis management in secondary schools as the main link in avoiding crises and preventing them.

- Create a specialized crisis management department in secondary schools.

- Spread awareness inside and outside the school about the importance of implementing crisis management and the use of scientific methods and approaches to deal with it.

- Train principals and staff in secondary schools on crisis management skills.

\section{References}

Abdul-Muttalib, Al Hout \& Tawfik (2018). The University's Strategic Planning Methodology. Journal of the College of Education. 29 (116): pp. 146-164.

Abdullah, Khamis (2018) .The Effectiveness of Secondary School Principals in Crisis Management in the Governorate of Muscat ,Fayoum University Journal for Educational and Psychological Sciences(3) 9 : Pp. $165-138$

Al-Juhani (2018) Methods of the Efficiency of School Leaders to Make Decisions in Managing School Crises. Resala Education and Psychology Journal. pp. 60

Al-Salhi .(2019) .The Status quo of the Application of High School Leaders in Managing School Crises in the Qassim Region. International Journal of Education through Internet. 18 (1): pp. 64-35

Al-Saud (2013). Educational Leadership, Concepts and Prospects. Safaa House for Publishing and Distribution, Jordan.

Al-Thuwain (2018) . A Proposed Program for Developing Crisis Management Skills for Secondary School Teachers in Ha'el. Islamic University of Educational and Psychological Studies Journal. 26 (5): pp. 135-109

Al Yahya (2006). Crisis Management in the Intermediate Government Schools for Girls in Madinah. King Saud University Journal.19 (1): pp. 247-380

Al-Yahyawi (2006) . Crisis Management in Government Middle Schools for Girls in Medina. Journal of Educational Sciences and Islamic Studies. (1)19

Hamdouna (2006). Secondary School Principals Practices in Crisis Management Skills in Gaza. Islamic

University. Gaza, Palestine. Unpublished Master's Thesis

Kahil (2015). A Proposed Model for Developing Crisis Management in Pre-University Education

Schools in the Light of Contemporary Administrative Thought, Damascus University Journal, 31 (2).

Liou (2015). School Crisis Management: A Model of Dynamic Responsiveness to Crisis Life Cycle.

Educational Administration Quarterly, Research article, 51(2): pp 247-289

Qasim (2017) . Management Tools and Business Development Methods. $1^{\text {st }}$ edition. Al Amal Press,

United Arab Emirates.

Rengifo, Ruz \& Mascareño (2018). Managing the 1920s' Chilean Educational Crisis: A Historical View

Combined with Machine Learning. PLOS ONE Journal, 13 (5) [Online] Available: https://journals.plos.org/plosone/article?id=10.1371/journal.pone.0197429 